\title{
Fatty acid profile and composition of milk protein fraction in dairy cows fed long-chain unsaturated fatty acids during the transition period
}

\author{
Francisco Palma Rennó ${ }^{1}$, José Esler de Freitas Júnior ${ }^{1}$, Jefferson Rodrigues Gandra', \\ Lenita Camargo Verdurico', Marcos Veiga dos Santos ${ }^{1}$, Rafael Villela Barletta ${ }^{1}$, Beatriz Conte \\ Venturelli ${ }^{1}$, Flávio Garcia Vilela ${ }^{1}$
}

\begin{abstract}
${ }^{1}$ Departamento de Nutrição e Produção Animal, Faculdade de Medicina Veterinária e Zootecnia, Universidade de São Paulo, Pirassununga, SP, Brasil.
\end{abstract}

\begin{abstract}
The objective of this study was to evaluate the utilization of different sources of unsaturated long-chain fatty acids in diets for dairy cows during the transition period and early lactation on the milk fatty acid profile and composition of the protein fraction. Thirty-six Holstein cows were divided into three groups, fed the following diets: control (C); soybean oil (SO); and calcium salts of long-chain unsaturated fatty acids (CS). The milk samples utilized for analysis were obtained weekly from parturition to twelve weeks of lactation; each one of the samples originated from two daily milkings. Milk composition and total nitrogen, non-protein nitrogen and non-casein nitrogen levels were analyzed. The cows receiving the diet with calcium salts had lower concentrations of non-protein nitrogen $(\% \mathrm{CP})$ in milk compared with the animals fed the diet with soybean oil. There was a decrease in concentration of medium-chain fatty acids $\mathrm{C} 12-\mathrm{C} 16$, and a concomitant increase in concentrations of long-chain fatty acids $>\mathrm{C} 18$ in milk fat for the animals fed the diets CS and SO when compared with diet C. Soybean oil and CS diets increased milk-fat concentrations of the acids C18: 1 trans-11, C18: 2 cis-9, trans-11 and C18: 2 trans-10 cis-12 in relation to diet $\mathrm{C}$. The utilization of sources of long-chain fatty acids in the diet of dairy cows increases the biological value of milk in early lactation due to higher concentrations of specific fatty acids such as CLA C18: 2 cis-9, trans-11.
\end{abstract}

Key Words: calcium salts of fatty acids, corn silage, soybean oil

\section{Introduction}

In the last decades, the evaluation of the composition of fatty acids present in ruminant milk supplemented with lipid sources has been the subject of several studies. This interest has stemmed precisely because of the presence of isomers of conjugated linoleic acids (CLA) cis-9 trans-11 and trans-10 cis-12, which have demonstrated beneficial biological effects confirmed in human nutrition, e.g. prevention of certain types of cancer, reduction of atherosclerosis, increase in immune response and assistance in human development (Whigham et al., 2000; Pariza, 2004; Palmquist et al., 2005).

The large number of research studies with the aim of increasing the biological value of animal products - more specifically the milk of ruminants -, comes from the FAO recommendations, which in 2003 established the consumption of saturated fatty acids (SFA) and trans FA for humans. However, only two processes can change the fatty acid profile of products derived from ruminants: modification of fatty acids during the processing, or change in the fatty acid profile of the diet (Allen, 2000; Palmquist, 2007; Jenkins, 2008).
In the process of inclusion of fat and digestion in ruminants, the majority of fatty acids is altered by ruminal metabolism, thus the biohydrogenation is usually not complete, resulting in a wide variety of fatty acids (Byers \& Schehing, 1993). Therefore, when there is incomplete biohydrogenation of polyunsaturated fatty acids, the duodenal flow of trans-fatty acids C18: 1 and conjugated linoleic acid cis-9, trans-11- CLA and trans-10, cis -12 - CLA increases, featuring the latest proven inhibitory effect on milk fat synthesis (Bauman \& Griinari, 2003; Peterson et al., 2003).

However, it is necessary to emphasize that the lipid metabolism, specifically the ruminal biohydrogenation, is influenced by several factors like rumen $\mathrm{pH}$; the amount, source and fatty acid profile of the fat supplement from the diet; the presence of ionophores; and protection of lipids (Allen, 2000; Chilliard et al., 2007).

The use of fat sources in diets for dairy cows can also promote reduction of milk protein content, although the production of protein has not been influenced, and in some cases, even increased. This reduction can occur by the simple effect of dilution due to the increase in production when fat sources are added to the diets (Garnsworthy, 2002), by variations in the concentrations of milk protein 
fractions, like casein concentration, or even by variations in some hormone concentrations that can promote physiological changes and affect milk protein synthesis (Wu et al., 1994).

According to Smith \& Harris (1993) and Onetti \& Grummer (2004), research results with use of fat in the diet of dairy cows suggest that the response in milk production and composition to fat supplementation is more variable when diets are totally or mostly based on corn silage as roughage.

Thus, the objective of this study was to evaluate the utilization of different sources of long-chain unsaturated fatty acids in diets for dairy cows during the transition period and early lactation on the milk fatty acid profile.

\section{Material and Methods}

Thirty-six multiparous and pregnant Holstein cows with expected parturition for 35 days after the initial supply of the experimental diets were used. The animals were evaluated during the prepartum period, with average live weight of $660 \pm 70.05 \mathrm{SD} \mathrm{kg}$, at parturition, and up to 84 days of lactation, with average live weight of $580 \pm 66.9$ SD kg. The cows were housed in free stalls provided with individual separation, so that each animal remained in its respective stall, to enable individual control of feed intake.

Diets were formulated according to requirements of the NRC (2001), and the animals were randomly distributed to receive the following experimental diets: control (C); soybean oil (SO), based on inclusion of 3.0\% soybean oil in the concentrate; and calcium salts of unsaturated fatty acids (Megalac-E ${ }^{\circledR}$, Química Geral do Nordeste - QGN and Arm \& Hammer, Inc.) (CS), based on the inclusion of 3\% calcium salts of fatty acids (Tables 1 and 2).

The quantities of forage and concentrates provided and the orts of each experimental diet were weighed daily for the estimate of individual intake. The animals were fed according to the dry matter intake (DMI) on the previous day, so that the daily percentage of orts from the diet was kept between $5 \%$ and $10 \%$ for animals not to have restricted consumption.

During the lactation period, the cows remained two hours per day in the morning and evening, after milking, resting in their stalls. Samples of the feed provided and orts were collected every day and mixed to form a composite sample relative to the period of one week and stored at $-20{ }^{\circ} \mathrm{C}$ for subsequent laboratory analysis.

In the feed provided and in the leftovers, samples were analyzed for the contents of dry matter (DM), mineral matter (MM), ether extract (EE) and crude protein (CP), according to the AOAC (1990). The total carbohydrate (TC) contents were calculated according to Sniffen et al. (1992): $\mathrm{TC}=100-(\% \mathrm{CP}+\% \mathrm{EE}+\% \mathrm{Ash}) ;$ and the non-fibrous carbohydrate (NFC) contents were estimated according to Hall (1998): $\mathrm{NFC}=100-[(\% \mathrm{CP}-\% \mathrm{CP}$ urea $+\%$ urea $)$ $+\% \mathrm{EE}+\% \mathrm{MM}+\% \mathrm{NDF}]$. The TDN was calculated according to Weiss et al. (1992): TDN (\%) = DCP + DNDF $+\mathrm{DNFC}+(\mathrm{DEE} \times 2.25)$, in which: $\mathrm{DCP}=$ digestible crude protein; $\mathrm{DNDF}=$ digestible fractions of NDF; DNFC = digestible non-fibrous carbohydrate; and DEE = digestible ether extract.

The contents of neutral detergent fiber (NDF) and acid detergent fiber (ADF), neutral detergent insoluble nitrogen (NDIN), acid detergent insoluble nitrogen (ADIN) and lignin were obtained according to the method described by Van Soest \& Mason (1991), using $\alpha$-amylase and without addition of sodium sulfite in the NDF determination, in an Ankon ${ }^{\circledR}$ System.

Cows were mechanically milked twice daily, at $06 \mathrm{~h} 30$ and $15 \mathrm{~h} 30$, with milk production recorded daily during all the experimental period. The milk samples utilized for analysis were obtained weekly from parturition to 12 weeks of lactation; each one of the samples originated from the two daily milkings.

The fractions of non-casein nitrogen and milk casein were determined by using the methodology described by Lynch \& Barbano (1998). Milk casein was precipitated in $\mathrm{pH} 4.6$ using acetic acid and sodium acetate solution. After precipitation, casein was separated by filtration and concentration of filtrated nitrogen (NNC), determined by the Kjeldahl method. The non-protein nitrogen was determined by the Kjeldahl method (AOAC, 1995), after previous preparation of milk samples, using trichloroacetic acid at $15 \%$ for coagulation of all milk proteins that were removed by filtration, and the filtrate was subjected to analyses. After the determination of non-protein nitrogen concentration, it was subtracted from the total nitrogen concentration, and in this way, the true protein concentration was determined. Casein concentration was determined by subtracting noncasein nitrogen from total nitrogen (TN). The serum protein was determined through the subtraction of the casein content from the milk true protein. The milk crude protein content was calculated by multiplying total nitrogen by 6.38 , in accordance with Barbano \& Clark (1990).

For the evaluation of the milk fatty acid profile, milk samples were initially centrifuged at $17,800 \times \mathrm{g}$ for 30 minutes at $4{ }^{\circ} \mathrm{C}$ and then at $19,300 \times \mathrm{g}$ for 20 minutes at $4{ }^{\circ} \mathrm{C}$, according to Feng et al. (2004). The separated fat (300-400 mg) was methylated and the methyl esters were formed according to Kramer et al. (1997). Two internal standards C18:0 and 
C19:0 were used to correct losses during the methylation process (Sukhija \& Palmquist, 1988).

Fatty acids were quantified by gas chromatography (GC Shimatzu 2010 with automatic injection) using a capillary column SP-2560 $(100 \mathrm{~m} \times 0.25 \mathrm{~mm}$ of diameter with $0.02 \mathrm{~mm}$ thickness, Supelco, Bellefonte, PA). The initial temperature was $70^{\circ} \mathrm{C}$ for 4 minutes $\left(13^{\circ} \mathrm{C} /\right.$ minute $)$ until reaching $175{ }^{\circ} \mathrm{C}$, keeping for 27 minutes. Next, the temperature was increased at a rate of $4{ }^{\circ} \mathrm{C} /$ minute until reaching $215{ }^{\circ} \mathrm{C}$, remaining so for 31 minutes. Hydrogen

Table 1 - Ingredients and chemical composition of the experimental diets

\begin{tabular}{|c|c|c|c|c|c|c|}
\hline \multirow{3}{*}{ Ingredients } & \multicolumn{6}{|c|}{ Experimental diets } \\
\hline & \multicolumn{3}{|c|}{ Prepartum } & \multicolumn{3}{|c|}{ Postpartum } \\
\hline & Control & Soybean oil & $\begin{array}{l}\text { Calcium salts of fatty acids } \\
\left(\text { Megalac- } \mathrm{E}^{\circledR}\right)\end{array}$ & Control & Soybean oil & $\begin{array}{c}\text { Calcium salts of fatty acids } \\
\left(\text { Megalac- } E^{\circledR}\right)\end{array}$ \\
\hline \multicolumn{7}{|c|}{$\mathrm{g} / \mathrm{kg}$ of $\mathrm{DM}$} \\
\hline Corn silage $^{1}$ & 750.2 & 750.2 & 750.2 & 470.2 & 470.2 & 470.2 \\
\hline Ground corn & 133.8 & 103.2 & 103.2 & 272.8 & 249.0 & 253.1 \\
\hline Soybean meal & 94.7 & 94.6 & 94.6 & 221.3 & 213 & 213 \\
\hline Calcium salts of fatty acids & - & - & 29.9 & - & - & 33.1 \\
\hline Soybean oil & - & 29.9 & - & - & 30.2 & \\
\hline Urea & 9.7 & 10.5 & 10.5 & 3.9 & 5.8 & 5.8 \\
\hline Ammonium sulfate & 0.8 & 0.8 & 0.8 & 0.5 & 0.5 & 0.5 \\
\hline Sodium bicarbonate & - & - & - & 8.1 & 8.1 & 8.1 \\
\hline Magnesium oxide & - & - & - & 2 & 2 & 2 \\
\hline Dicalcium phosphate & 0.8 & 0.8 & 0.8 & 5.5 & 5.5 & 5.5 \\
\hline Limestone & 4 & 4 & 4 & 9.9 & 9.9 & 2.9 \\
\hline Mineral $^{2}$ & 2.8 & 2.8 & 2.8 & 2.6 & 2.6 & 2.6 \\
\hline Vitamins $^{3}$ & 1.6 & 1.6 & 1.6 & - & - & - \\
\hline Salt & 1.6 & 1.6 & 1.6 & 3.2 & 3.2 & 3.2 \\
\hline \multicolumn{7}{|l|}{ Nutrients, $\mathrm{g} / \mathrm{kg}$ of DM } \\
\hline Dry matter & 475.4 & 478.1 & 474.5 & 618 & 619.4 & 615.3 \\
\hline Organic matter & 924.1 & 925.8 & 918.4 & 925.1 & 926.8 & 928.4 \\
\hline Crude ash & 75.8 & 74.1 & 81.5 & 74.9 & 73.2 & 71.6 \\
\hline Crude protein & 156.8 & 151.2 & 151.2 & 187.9 & 186.8 & 187.2 \\
\hline Non-fibrous carbohydrates & 407.8 & 377.8 & 386.2 & 456.6 & 417.9 & 419.5 \\
\hline $\mathrm{ADICP}^{4}$ & 152.3 & 151.2 & 151.2 & 114.8 & 118.3 & 118.5 \\
\hline $\mathrm{NDICP}^{4}$ & 162.2 & 164.5 & 161 & 163.3 & 162.8 & 162.9 \\
\hline Ether extract & 27.3 & 55.9 & 50.5 & 28.3 & 56.9 & 54.1 \\
\hline Neutral detergent fiber & 472.1 & 465.6 & 465.6 & 362.4 & 356 & 356.9 \\
\hline Acid detergent fiber & 298.2 & 295.4 & 295.4 & 212.1 & 210 & 210.2 \\
\hline Lignin & 45.2 & 44.2 & 44.7 & 34.8 & 33.7 & 33.7 \\
\hline Total carbohydrates & 737.6 & 712.4 & 717.7 & 694.7 & 662.8 & 665.1 \\
\hline Total digestible nutrients & 668.3 & 696.1 & 689.7 & 755.5 & 760.7 & 756.7 \\
\hline $\mathrm{NEL}^{5}$ & 1.19 & 1.26 & 1.27 & 1.68 & 1.74 & 1.76 \\
\hline
\end{tabular}

ADICP - acid detergent indigestible crude protein; NDICP - neutral detergent indigestible crude protein; NEL - net energy for lactation.

${ }^{1}$ Corn silage contains: $34.44 \%$ DM (natural matter) and $48.50 \%$ NDF; $7.50 \%$ CP; $10.07 \%$ mineral matter in dry matter, $1.47 \mathrm{NEL} / \mathrm{kg}$ of DM.

${ }^{2}$ Composition per kg of product: $\mathrm{Mg}-10 \mathrm{~g}$; $\mathrm{S}-9 \mathrm{~g}$; Zn - 23,750 mg; Cu - 5,625 mg; Mn - 18,125 mg; Fe - 5,000 mg; Co - $125 \mathrm{mg}$; I - $312 \mathrm{mg}$; Se - $144 \mathrm{mg}$; F (max.) - 900 mg; vit. A - 2,000 IU; vit. E - 12,500 mg; vit. D - 5,000 IU.

${ }^{3}$ Composition per kg of product: vit. A - 8,000 IU; vit. E - 50,000 IU; vit. D - 2,300 IU.

${ }^{4}$ Expressed as percentage of total nitrogen.

${ }^{5} \mathrm{Mcal} / \mathrm{kg} / \mathrm{DM}$.

Table 2 - Fatty acid composition of experimental diets

\begin{tabular}{|c|c|c|c|c|c|c|}
\hline \multirow{3}{*}{ Ingredients } & \multicolumn{6}{|c|}{ Experimental diets } \\
\hline & \multicolumn{3}{|c|}{ Prepartum } & \multicolumn{3}{|c|}{ Postpartum } \\
\hline & Control & Soybean oil & $\begin{array}{l}\text { Calcium salts of fatty acids } \\
\left(\text { Megalac- } E^{\circledR}\right)\end{array}$ & Control & Soybean oil & $\begin{array}{l}\text { Calcium salts of fatty acids } \\
\left.\text { (Megalac- } E^{\circledR}\right)\end{array}$ \\
\hline \multicolumn{7}{|c|}{ Fatty acids (g/100 g) } \\
\hline C14:0 & 0.45 & 0.45 & 0.46 & 0.34 & 0.34 & 0.35 \\
\hline C16:0 & 16.71 & 16.66 & 16.60 & 15.28 & 15.18 & 15.19 \\
\hline C18:0 & 3.16 & 3.18 & 3.14 & 3.11 & 3.12 & 3.10 \\
\hline $\mathrm{C} 18: 1 \mathrm{cis}$ & 12.35 & 12.59 & 12.61 & 12.33 & 12.56 & 12.70 \\
\hline C18:2 (n-6) & 26.97 & 27.12 & 26.95 & 32.86 & 32.92 & 33.04 \\
\hline C18:3 (n-3) & 1.37 & 1.31 & 1.26 & 2.93 & 2.88 & 2.87 \\
\hline Other & 3.69 & 3.68 & 3.84 & 2.74 & 2.71 & 2.88 \\
\hline
\end{tabular}


Table 3 - Fatty acid composition of ingredients

\begin{tabular}{|c|c|c|c|c|c|}
\hline \multirow[b]{2}{*}{ Ingredients } & \multicolumn{5}{|c|}{ Ingredients } \\
\hline & Soybean oil & $\begin{array}{l}\text { Calcium salts of fatty } \\
\text { acids }\left(\text { Megalac- } E^{\circledR}\right)\end{array}$ & Ground corn & Corn silage & Soybean meal \\
\hline \multicolumn{6}{|c|}{ Fatty acids (g/100 g) } \\
\hline C14:0 & 0.55 & 0.14 & 0.07 & 1.20 & 0.56 \\
\hline $\mathrm{C} 16: 0$ & 10.22 & 8.04 & 11.55 & 18.17 & 16.21 \\
\hline C18:0 & 3.77 & 2.37 & 3.24 & 3.24 & 3.17 \\
\hline C18:3 & 4.87 & 3.35 & 6.60 & - & 5.11 \\
\hline Others & - & 5.21 & 0.42 & 4.58 & 2.11 \\
\hline
\end{tabular}

$\left(\mathrm{H}_{2}\right)$ was used as carrier gas with a flow rate of $40 \mathrm{~cm}^{3} / \mathrm{s}$. During the identification process, four patterns were used to identify the fatty acids that were formed during the biohydrogenation of unsaturated fatty acids: standard C4-C24 of fatty acids (Supelco ${ }^{\circledR}$ TM 37), vacenic acid C18: 1 trans-11 (V038- 1G, Sigma ${ }^{\circledR}$ ), CLA C18: 2 trans-10, cis-12 (UC-61M $100 \mathrm{mg}$ ), CLA and C18: 2 cis-9, trans-11 (UC-60M $100 \mathrm{mg}$ ), (NU-CHEK-PREP, USA ${ }^{\circledR}$ ).

To evaluate the fatty acid profile of the feeds, the extraction process was performed according to Folch et al. (1957) and the separated fat was methylated and the methyl esters were formed according to Kramer et al. (1997). The quantification procedure was performed similarly to the analysis of milk.

The index of the enzyme delta-9-desaturase, $(\Delta 9$ dasaturase) was calculated according to Corl et al. (2001), in which: $(\mathrm{C} 16: 1+\mathrm{C} 18: 1$ cis-9 + C18:1 cis-1)/(C14:0 + C16:0 + C18:0 + C16:1 + C18:1 cis-9 + C18:1 cis-11).

The randomized experimental design based on the expected date of calving was used for formation of the experimental groups. The collected data were analyzed using PROC MIXED of SAS software (Statistical Analysis System, version 9.2). The concentrations of productive performance, fatty acids and protein fractions were analyzed using in the model effect of treatment (diet), the time (weeks) and the interaction between time and treatment as fixed effects, according to the model:

$$
\mathrm{Y}_{\mathrm{ij}}=\mu+\mathrm{D}_{\mathrm{i}}+\mathrm{W}_{\mathrm{j}}+\mathrm{D}_{\mathrm{i}}\left(\mathrm{W}_{\mathrm{j}}\right)+\mathrm{e}_{\mathrm{ij}}
$$

in which: $\mu=$ mean, $D_{i}=$ fixed effect of diet; $\mathrm{W}_{\mathrm{j}}=$ fixed effect of week (weeks), $\mathrm{D}_{\mathrm{i}}\left(\mathrm{W}_{\mathrm{j}}\right)$ = week * diet interaction; and $\mathrm{e}_{\mathrm{ij}}=$ random error. The above model was used for analysis of pre-and postpartum, and the delivery time variable pre weeks $-4,-3,-2,-1$ weeks in relation to parturition and postpartum weeks 1 to 12 . The effect of animal was considered random.

In the analysis of weight, body condiction score measurements performed at 35 days prepartum and postpartum were used as covariates in the model at the level of $5 \%$ of probability pre- and postpartum, respectively.
The model was fitted by assuming four different variance-covariance structures: variance components or independent errors; compound symmetry with constant correlations among repeated measures; first-order autoregressive correlations; and unstructured or unconstrained variance-covariance structure. The structures of variancecovariance were selected according to the Akaike information criterion. The best variance-covariance structure tested for this trial was $\operatorname{AR}(1)$, and it was used for all analysis.

To evaluate the effects of treatments, the following orthogonal contrasts were considered: $\mathrm{C} 1=$ control diet (C) versus soybean oil (SO), and calcium salts (CS); the objective was to compare the sources of fat with control diet regardless of sources of long chain fatty acids used; $\mathrm{C} 2$ = soybean oil diet versus calcium salts of fatty acids; the objective was to evaluate the differences between the sources of long-chain fatty acids tested.

To perform regression analysis for weeks of lactation, PROC IML of SAS (Statistical Analysis System, version 9.2) with the function ORPOL was used to obtain the coefficients of polynomials relating to weeks of lactation. After obtaining the coefficients, PROC MIXED was used to obtain the probability values of a linear or quadratic effect and cows was used as random effect. To obtain the regression equations and the correlation coefficient, PROC MIXED (SAS, version 9.2) was used. The maximum point was extracted according to the first derivative at a seconddegree equation.

\section{Results}

There was no effect of experimental diets on DMI in the prepartum period (Figure 1b). In the postpartum period, the animals subjected to the diets with fat sources presented lower DM intake in comparison with the control diet $(\mathrm{P}<0.032$; Table 4). Cows fed the CS and SO diets showed lower BW in the postpartum period (Figure 1c). Diets had no effect on milk yield or body condition score (BCS) in 
the prepartum period. However, the cows fed the CS and SO diets showed lower BCS in the postpartum period. The average BW and BCS were $649 \pm 39 \mathrm{~kg}$ and $2.9 \pm 0.2$ in the prepartum period and $584 \pm 20 \mathrm{~kg}$ and $2.5 \pm 0.1$ in the postpartum period, respectively. The BCS were altered according to week of lactation in the postpartum period.
According to Grummer (1991) and Palmquist (1991), the fatty acid composition of the diet changes the fatty acid profile of milk fat and transfer of dietary fatty acids to milk fat may be influenced by three main factors: the ruminal biohydrogenation; digestibility and absorption; and deposit in adipose tissue. Moreover, the most common variation of
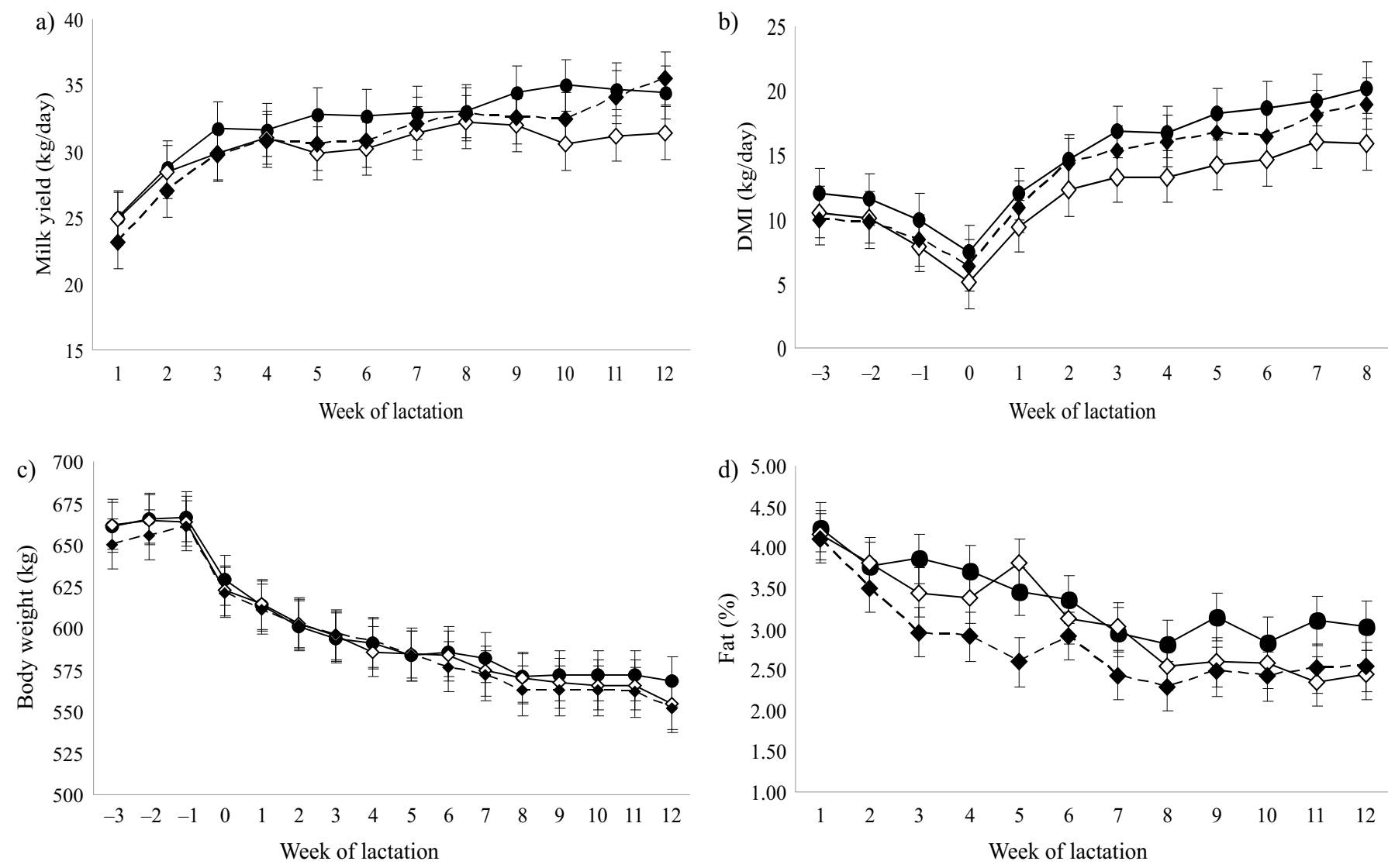

The MY did not differ between diets (MY; $\mathrm{P}=0.740)$, (FCM; $\mathrm{P}=0.076)$. There was effect $(\mathrm{P}<0.001)$ of the weeks relative to the partum on $\mathrm{MY}$, FCM, fat yield and percentage of milk fat. There was no interaction between diets and weeks relative to calving on MY, FCM, fat yield and percentage of milk fat.

Figure 1 - Milk yield (MY; a), dry matter intake (DMI; b), body weight (c) and percentage of fat (d), in the first 12 weeks of lactation for cows fed diets control $(\mathrm{C} ;-\bullet-)$, soybean oil $(\mathrm{SO} ;-\diamond-)$ or calcium salts of fatty acid ( $\mathrm{CS} ;----)$.

Table 4 - Effect of experimental diets on feed intake, body condition score, body weight and milk production

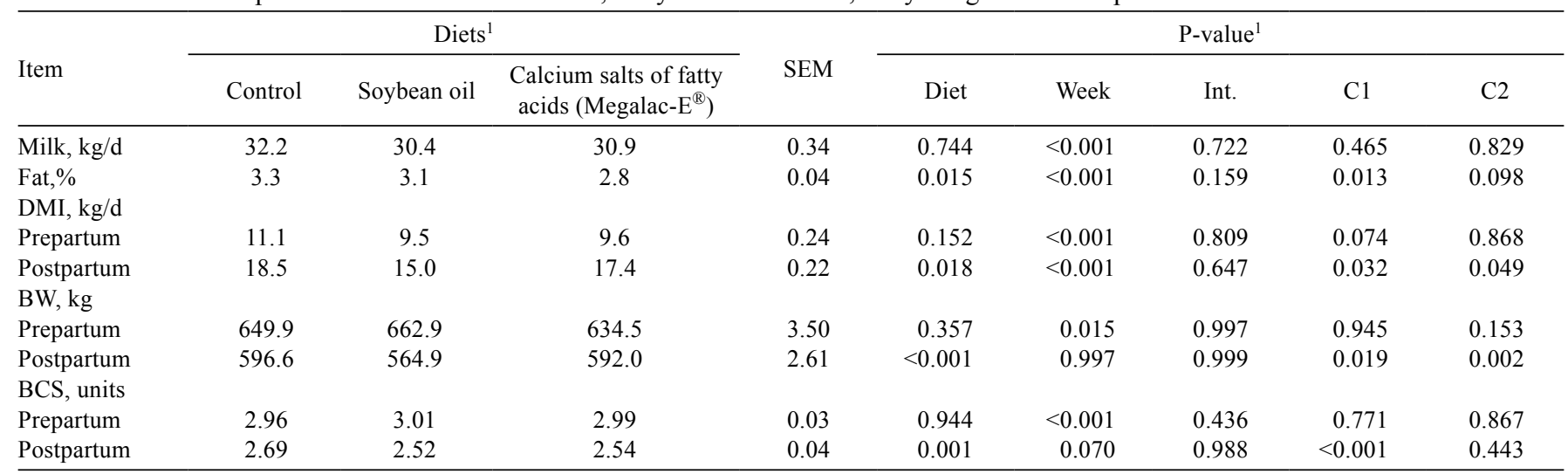

SEM - standard error of the mean; C1 - control diet vs soybean oil and calcium salts; C2 - soybean oil diet vs. calcium salts.

${ }^{1}$ Probability value of multivariate analysis considering the fixed effects of diet, time and interaction of the two variables. 
fatty acids (FA) in the milk according to these authors is caused by true digestibility.

In this study, the concentrations of long-chain fatty acids (LCFA), medium-chain fatty acids (MCFA) and C6 acid decreased, with a concomitant increase in the concentrations of long-chain fatty acids with more than 18 carbons in the milk fat of animals subjected to diets CS and $\mathrm{SO}$ when compared with $\operatorname{diet} \mathrm{C}(\mathrm{P}<0.05$; Table 3$)$. However, the concentrations of butyric acid (C4) were not altered by the experimental diets. With the decrease in concentration of fatty acids $<\mathrm{C} 16$, the concentrations of acids with 16 to 18 carbons for animals subjected to the $\mathrm{CS}$ and $\mathrm{SO}$ diets were higher in relation to diet $\mathrm{C}(\mathrm{P}<0.05$; Table 5).

There was effect of the lactation weeks on the concentrations of fatty acids $<\mathrm{C} 16$. The animals that received the $\mathrm{SO}$ and $\mathrm{CS}$ diets showed higher concentrations of fatty acids $>\mathrm{C} 16$ and lower concentrations of fatty acids $<\mathrm{C} 16$ in relation to the $\mathrm{C} \operatorname{diet}(\mathrm{P}<0.05$; Table 5).

There was effect of diets on the concentrations of fatty acids $<\mathrm{C} 16$ along the twelve weeks of lactation $(\mathrm{P}<0.05$; Table 4$)$. The highest concentrations of fatty acids $>\mathrm{C} 16$ occurred at about the seventh week postpartum according the greater DMI, ether extract intake and higher milk production (Table 4).

The animals that received the $\mathrm{C}$ diet presented a higher ratio $<\mathrm{C} 16 / \mathrm{C} 18$ when compared with those fed diets $\mathrm{CS}$ and SO $(\mathrm{P}<0.001$; Table 5). The highest concentrations of $\mathrm{FA}<\mathrm{C} 16$ in milk were observed in the seventh week of lactation in animals receiving the $\mathrm{C}$ diet $(\mathrm{P}<0.001)$. Similarly, the lowest concentrations of $>\mathrm{C} 16$ were observed in the milk from the animals that received diet $\mathrm{C}$, in the sixth, seventh and twelfth weeks of lactation $(\mathrm{P}<0.001)$. In relation to low concentrations of fatty acids $<\mathrm{C} 16$, the production of $\mathrm{C}: 14$ stood out and was clearly reduced in the milk from animals supplemented with diets containing fat $(\mathrm{P}<0.05$; Table 5). The concentrations of $\mathrm{C} 18: 2$ were increased for the cows fed the CS and SO diets in relation to diet $\mathrm{C}(\mathrm{P}<0.05$; Table 4). Evaluating the differences between sources of fat, the CS diet showed higher production of C18: 2 in relation to the $\mathrm{SO} \operatorname{diet}(\mathrm{P}<0.05$; Table 4). This result can be justified by the increased passage of this fatty acid through the rumen without undergoing

Table 5 - Milk fatty acid profile obtained for experimental diets

\begin{tabular}{|c|c|c|c|c|c|c|c|c|c|}
\hline \multirow[b]{2}{*}{ Item } & \multicolumn{3}{|c|}{ Experimental diets } & \multirow[b]{2}{*}{ SEM } & \multicolumn{5}{|c|}{ P-value $^{1}$} \\
\hline & Control & Soybean oil & $\begin{array}{l}\text { Calcium salts of fatty } \\
\left.\text { acids (Megalac- } E^{\circledR}\right)\end{array}$ & & Diet & Week & Int. & $\mathrm{C} 1$ & $\mathrm{C} 2$ \\
\hline \multicolumn{10}{|l|}{$\mathrm{g} / 100 \mathrm{~g}$ of $\mathrm{FA}$} \\
\hline $4: 0$ & 0.97 & 0.87 & 0.90 & 0.04 & 0.476 & 0.534 & 0.340 & 0.294 & 0.546 \\
\hline $6: 0$ & 0.92 & 0.60 & 0.56 & 0.01 & $<0.001$ & $<0.001$ & 0.003 & $<0.001$ & 0.770 \\
\hline $8: 0$ & 0.62 & 0.34 & 0.30 & 0.01 & $<0.001$ & $<0.001$ & $<0.001$ & $<0.001$ & 0.642 \\
\hline $10: 0$ & 1.47 & 0.74 & 0.67 & 0.03 & $<0.001$ & $<0.001$ & $<0.001$ & $<0.001$ & 0.744 \\
\hline $12: 0$ & 1.71 & 0.92 & 0.88 & 0.03 & $<0.001$ & $<0.001$ & $<0.001$ & $<0.001$ & 0.954 \\
\hline $14: 0$ & 6.44 & 4.13 & 3.88 & 0.10 & $<0.001$ & $<0.001$ & $<0.001$ & $<0.001$ & 0.761 \\
\hline $15: 0$ & 0.57 & 0.46 & 0.39 & 0.01 & $<0.001$ & $<0.001$ & 0.195 & $<0.001$ & 0.078 \\
\hline $16: 0$ & 29.13 & 24.61 & 25.91 & 0.18 & $<0.001$ & $<0.001$ & 0.262 & $<0.001$ & 0.020 \\
\hline $16: 1 \mathrm{cis}$ & 1.46 & 1.25 & 1.23 & 0.02 & 0.226 & 0.005 & 0.078 & 0.091 & 0.831 \\
\hline $17: 0$ & 0.34 & 0.31 & 0.31 & 0.01 & 0.020 & 0.001 & 0.015 & 0.005 & 0.955 \\
\hline $18: 0$ & 9.13 & 10.93 & 10.18 & 0.13 & 0.025 & $<0.001$ & 0.094 & 0.018 & 0.181 \\
\hline 18:1 trans & 1.08 & 2.25 & 3.13 & 0.07 & $<0.001$ & 0.040 & 0.014 & $<0.001$ & 0.006 \\
\hline 18:1cis 9 & 20.89 & 23.28 & 21.54 & 0.34 & 0.540 & $<0.001$ & 0.182 & 0.347 & 0.564 \\
\hline $18: 2 \mathrm{n}-6$, trans & 0.01 & 0.04 & 0.04 & 0.01 & 0.021 & 0.828 & 0.077 & 0.006 & 0.868 \\
\hline $18: 2 \mathrm{n}-6, \mathrm{cis}$ & 1.78 & 2.03 & 2.58 & 0.03 & $<0.001$ & 0.020 & 0.118 & $<0.001$ & $<0.001$ \\
\hline $20: 0$ & 0.06 & 0.07 & 0.07 & 0.01 & 0.073 & 0.283 & $<0.001$ & 0.066 & 0.182 \\
\hline cis-9,trans-11 & 0.27 & 0.43 & 0.39 & 0.01 & 0.006 & 0.001 & 0.178 & 0.002 & 0.531 \\
\hline trans -10, cis -12 & 0.00 & $<0.01$ & $<0.02$ & 0.01 & 0.007 & $<0.001$ & $<0.001$ & 0.052 & 0.008 \\
\hline \multicolumn{10}{|l|}{ Total } \\
\hline$<\mathrm{C} 16$ & 13.80 & 8.76 & 8.19 & 0.23 & $<0.001$ & $<0.001$ & $<0.001$ & $<0.001$ & 0.729 \\
\hline $\mathrm{C} 16$ & 30.60 & 25.86 & 27.15 & 0.15 & $<0.001$ & 0.002 & 0.159 & $<0.001$ & 0.024 \\
\hline$>\mathrm{C} 16$ & 19.46 & 25.11 & 25.28 & 0.36 & 0.037 & 0.445 & 0.735 & 0.031 & 0.696 \\
\hline Unsat. C18 & 23.81 & 28.11 & 27.45 & 0.36 & 0.071 & 0.004 & 0.183 & 0.026 & 0.956 \\
\hline Unsat./Sat. C18 & 2.65 & 2.56 & 2.78 & 0.03 & 0.223 & $<0.001$ & $<0.001$ & 0.666 & 0.095 \\
\hline Saturated & 51.55 & 44.08 & 44.13 & 0.33 & $<0.001$ & 0.003 & $<0.001$ & $<0.001$ & 0.865 \\
\hline Unsaturated & 23.81 & 27.86 & 27.45 & 0.36 & 0.092 & 0.005 & 0.192 & 0.030 & 0.939 \\
\hline Uns/Sat. & 0.37 & 0.54 & 0.47 & 0.01 & 0.180 & $<0.001$ & 0.516 & 0.095 & 0.422 \\
\hline$<\mathrm{C} 16 / \mathrm{C} 18$ & 0.45 & 0.23 & 0.22 & 0.01 & $<0.001$ & $<0.001$ & $<0.001$ & $<0.001$ & 0.965 \\
\hline$\Delta^{9}-$ Desaturase & 0.16 & 0.23 & 0.21 & 0.01 & 0.172 & 0.181 & 0.143 & 0.069 & 0.676 \\
\hline
\end{tabular}

SEM - standard error of the mean; Int. - week $\times$ diet interaction; C1 - control diet vs. soybean oil and calcium salts; C2 - soybean oil diet vs. calcium salts. 
biohydrogenation, which confirms the protection of this fat source by the industrial method.

The concentrations of the vacenic acids C18: 1 trans, CLA C18:2 cis-9, trans-11 and CLA C18: 2 trans-10 cis-12 in milk fat were higher for the cows that received the SO and $\mathrm{CS}$ diets in relation to diet $\mathrm{C}(\mathrm{P}<0.05$; Table 5). Consistently, high concentrations of these fatty acids occurred when the fat percentage stabilized and when there was higher MY ( 7 to 8 weeks postpartum; Table 4$)(\mathrm{P}<0.001)$. There was linear and quadratic effect on the concentrations of fatty acids CLA C18:2 cis-9 along twelve weeks of lactation $(\mathrm{P}<0.05$; Table 5). However, the concentration of $\mathrm{C} 18: 1$ - trans showed only quadratic effect (Table 5). The linear effects of the weeks of lactation can be explained by increased consumption of fat supplements.

Among the sources of fat utilized, the cows that were fed the CS diet showed higher concentrations of acid C18: 1 trans 11, and CLA C18: 2 trans-10 cis-12.

There were no effects of diets on the percentage of milk crude protein, non-protein nitrogen, non-casein nitrogen, true protein, casein $(\%)$, casein/total protein or whey protein (\%) (Table 7). There was effect of the week of lactation on crude protein concentration, non-protein nitrogen, noncasein nitrogen, true protein and casein $(\mathrm{P}<0.001$; Table 7).

\section{Discussion}

According to Grummer (1995), the reduction of DMI and its intensity in the prepartum may be related to several factors including body condition and the effect of diet. In this study, the reduction in DMI in the postpartum period for the CS and SO diets can be attributed to the effect of supplementation and energy density of diets with fat sources, which led the animals to reach metabolic satiety faster in relation to the control group.

Milk production did not differ between cows fed the control and unsaturated fatty acid treatments. According to Rabiee et al. (2012), in a meta-analysis of 200 papers, the inclusion of fat in the diets for dairy cows had marked effects on milk yield and milk fat and protein concentration. The authors concluded that this effect may be explained by the low dry matter intake coupled to lower milk yield. Moallem et al. (2007) observed lower intake for cows supplemented with calcium salts of fatty acids in relation to other fat sources. Addition of calcium salts of fatty acids to diets of dairy cows results in linear decrease in dry matter intake. However, in some studies there was increase in the intake (Allen, 2005). These results can be attributed to the low heat increment of fat during periods of heat stress, or

Table 6 - Regression analysis according to the weeks of lactation

\begin{tabular}{|c|c|c|c|c|c|c|}
\hline Item & Equation & $\mathrm{L}^{1}$ & $\mathrm{Q}^{1}$ & $\mathrm{R}^{2}$ & $\hat{\mathrm{Y}}$ & Maximum point (week) \\
\hline$<\mathrm{C} 16$ & $\hat{\mathrm{Y}}=7.683+0.408 * \mathrm{X}$ & $<0.001$ & 0.448 & 0.38 & - & - \\
\hline$>\mathrm{C} 16$ & $\hat{\mathrm{Y}}=24.001-0.158 * \mathrm{X}$ & 0.007 & 0.710 & 0.07 & - & - \\
\hline $\mathrm{C} 16$ & $\hat{\mathrm{Y}}=28.119-0.288 * \mathrm{X}+0.029 * \mathrm{X}^{2}$ & 0.011 & 0.016 & 0.17 & 27.40 & 5 th \\
\hline $\mathrm{C} 18: 2 \mathrm{c} 9, \mathrm{t} 11$ & $\hat{\mathrm{Y}}=0.2779+0.0344 * \mathrm{X}-0.0024 * \mathrm{X}^{2}$ & 0.054 & 0.002 & 0.05 & 0.40 & 7 th \\
\hline $\mathrm{C} 18: 1 \mathrm{t} 11$ & $\hat{Y}=1.623+0.225 * X-0.017 * X^{2}$ & 0.379 & 0.015 & 0.29 & 2.36 & 6 th \\
\hline Total unsaturated FA & $\hat{Y}=20.512+0.348 * X-0.0387 * X^{2}$ & 0.005 & 0.018 & 0.02 & 21.28 & 5 th \\
\hline Total saturated FA & $\hat{Y}=11.919-0.467 * X+0.0226 * X^{2}$ & $<0.001$ & 0.044 & 0.08 & 9.51 & 10 th \\
\hline
\end{tabular}

${ }^{1}$ Probability value with linear (L) or quadratic effect $(\mathrm{Q})$.

FA - fatty acids

Table 7 - Milk protein fractions according to the experimental diets

\begin{tabular}{|c|c|c|c|c|c|c|c|c|c|}
\hline \multirow[b]{2}{*}{ Item } & \multicolumn{3}{|c|}{ Experimental diets } & \multirow[b]{2}{*}{ SEM } & \multicolumn{5}{|c|}{ P-value ${ }^{1}$} \\
\hline & Control & Soybean oil & $\begin{array}{l}\text { Calcium salts of fatty } \\
\left.\text { acids (Megalac- } E^{\mathbb{R}}\right)\end{array}$ & & Diet & Week & Int. & $\mathrm{C} 1$ & $\mathrm{C} 2$ \\
\hline Non-protein N (g/kg) & 2.4 & 2.5 & 2.3 & 0.1 & 0.198 & 0.078 & 0.243 & 0.740 & 0.079 \\
\hline Non-protein $\mathrm{N}(\mathrm{g} / \mathrm{kg}, \mathrm{CP})$ & 87.1 & 90.3 & 82.6 & 1.0 & 0.125 & 0.022 & 0.883 & 0.870 & 0.043 \\
\hline Non-casein N (g/kg) & 7.3 & 7.5 & 7.4 & 0.1 & 0.824 & $<0.001$ & 0.818 & 0.538 & 0.964 \\
\hline Non-casein N (g/kg, CP) & 260.0 & 269.5 & 264.4 & 2.9 & 0.672 & 0.582 & 0.764 & 0.465 & 0.614 \\
\hline Casein $(\mathrm{g} / \mathrm{kg})$ & 21.1 & 20.6 & 21.2 & 0.21 & 0.861 & $<0.001$ & 0.529 & 0.895 & 0.599 \\
\hline Casein $(\mathrm{g} / \mathrm{kg}, \mathrm{CP})$ & 739.6 & 729.0 & 735.0 & 2.9 & 0.672 & 0.582 & 0.764 & 0.465 & 0.614 \\
\hline Casein/TP & 8.1 & 8.0 & 8.0 & 0.1 & 0.692 & 0.760 & 0.783 & 0.424 & 0.770 \\
\hline Whey protein $(\mathrm{g} / \mathrm{kg})$ & 4.9 & 5.0 & 5.3 & 0.1 & 0.441 & $<0.001$ & 0.978 & 0.363 & 0.369 \\
\hline Whey protein $(\mathrm{g} / \mathrm{kg}, \mathrm{CP})$ & 1.7 & 1.8 & 1.9 & 0.1 & 0.524 & 0.863 & 0.703 & 0.359 & 0.505 \\
\hline
\end{tabular}

C - control; SO - soybean oil; CS - calcium salts of fatty acids (Megalac-E ${ }^{\circledR}$ ); SEM - standard error of the mean; Int. - week $\times$ diet interaction; C1 - control diet vs. soybean oil and calcium salts; $\mathrm{C} 2$ - soybean oil diet $v s$. calcium salts.

$\mathrm{CP}$ - crude protein; $\mathrm{TP}$ - total protein.

${ }^{1}$ Probability value of multivariate analysis considering the fixed effects of diet, time and interaction of the two variables. 
to the reduction of propionate production when fat sources substituted grains in the diets (NRC, 2001).

The increase in the concentrations of long-chain fatty acids with over 18 carbons can be attributed to the increase in the fatty acid intake of cows fed the CS and SO diets when compared with diet C. However, according McCarthy et al. (1972), butyric acid is a short-chain fatty acid that undergoes few alterations in its concentrations in milk due to dietary changes.

The fact that the animals fed the SO and CS diets showed higher concentrations of fatty acids $>\mathrm{C} 16$ and lower concentrations of fatty acids $<\mathrm{C} 16$ in relation to the $\mathrm{C}$ diet can be, according to Palmquist (1993), a typical response of cows in early lactation. According to this author, the stage of lactation and the seasonal effect represent the two main factors that alter the fatty acid profile in milk from dairy herds.

Physiologically, in early lactation, dairy cows, especially those of high production, remain in negative energy balance (NEB) for long periods, causing mobilization of LCFA of the body reserves (adipose tissue) and increasing the concentrations of non-esterified fatty acids (NEFA) and very low-density lipoproteins (VLDL) will be captured by the mammary gland and used for formation of milk fat (Chilliard et al., 2000).

Concomitantly, high blood concentrations of LCFA inhibit the de novo synthesis of SCFA in the mammary gland. Palmquist (1993) evaluated the concentrations of fatty acids $\mathrm{C} 4, \mathrm{C} 6, \mathrm{C} 8, \mathrm{C} 10, \mathrm{C} 12, \mathrm{C} 14, \mathrm{C} 16$ and $\mathrm{C} 18$ in the first twelve weeks of lactation in dairy cows. According to this author, two typical responses are expected when these physiological changes occur during early lactation: the concentrations of SCFA in milk, except for C4, show low in early lactation; inhibition of synthesis of SCFA occurs by different variations related to the concentrations of fatty acids C:6 and C:12. In this study, this result can be analyzed through the proportions of SCFA and LCFA $(<\mathrm{C} 16 / \mathrm{C} 18)$ (Table 5).

This explanation justifies the linear effect for the concentrations of fatty acids $<\mathrm{C} 16$ along the twelve weeks of lactation (Table 5). This is because the concentrations of fatty acids $<\mathrm{C} 16$ and $>\mathrm{C} 16$ are inversely proportional, that is, when the concentrations of fatty acids $>\mathrm{C} 16$ were increased at about the seventh week, the concentrations of fatty acids $<\mathrm{C} 16$ in this period decreased.

The decrease in concentrations of fatty acids C6-C18, in total fatty acid $<\mathrm{C} 16$, and production of $<\mathrm{C} 16 / \mathrm{C} 18$ can be attributed to the elevation of cis- 9 , trans-11, and trans10, cis-12, CLA milk concentrations, which are present in greater amounts in the milk of cows fed the diets that contain the fatty-acid sources (Havertine \& Allen, 2006; Palmquist, 2007). This result indicates that diets containing additional fatty acid sources underwent an incomplete rumen biohydrogenation process, which could have caused reduction of the $\Delta^{9}$ desaturase enzyme activity (Cortês et al., 2010), modifying the process of fatty acid synthesis in the mammary gland.

To discuss the concentrations of fatty acids in milk, it is necessary to consider various physiological factors such as extract ether intake, dry matter intake, change in body condition score and energy balance. The milk yield (MY) was not influenced by experimental diets and animals subjected to diets CS, and SO reduced the DMI in the postpartum period compared with the animals on $\operatorname{diet} \mathrm{C}$. In contrast, there was increased consumption of EE for the CS and SO diets, in relation to diet C (1009 and 1220 vs. $780 \mathrm{~g} /$ day, respectively).

The low production of $\mathrm{C} 14$ in the milk from animals supplemented with diets containing fat sources $(\mathrm{P}<0.05$; Table 4) was similar to the observed by Clapperton \& Banks (1985), who demonstrated in a study with utilization of fat in the diet of dairy cows that the concentration of C14:0 increased significantly in animals that received the control diet, while the animals that received diets with fat sources decreased the concentrations of C14:0. These authors concluded that the reduction of the de novo synthesis caused by sources of fat in early lactation reaches $80 \%$ when compared with the diet without fat supplement.

The increased production of $\mathrm{C} 18: 2$ for the CS diet in relation to the $\mathrm{SO}$ diet $(\mathrm{P}<0.05$; Table 4$)$ can be attributed to greater protection of unsaturated fatty acids in the form of calcium salts favoring a greater passage of $\mathrm{C} 18: 2$ for absorption in the gut. Cortês et al. (2010) and Wu et al. (1991) evaluated different sources of calcium salts of fatty acids and observed that all the supplements reduced the concentrations of fatty acids ranging between $\mathrm{C} 8$ and $\mathrm{C} 15$. However, changes in the concentrations of $\mathrm{C} 16, \mathrm{C} 18$ and C18:1 were dependent on the quantity of these fatty acids in the diet. The highest concentrations of C18:2 observed by this author for animals supplemented with calcium salts of fatty acids in palm oil resulted in values similar to those obtained in this study although the calcium salts of fatty acids used in this work were different, coming from soybean oil composed mainly of long-chain fatty acids (C18:2 and C18:3). Harvatine \& Allen (2006) also observed similar results in the composition of FA of the milk from cows in early lactation supplemented with sources of fatty acids. Piperova et al. (2002) evaluated different fat supplements and observed that the level and composition 
of the supplement also changed the concentrations of fatty acids $\mathrm{C} 16$ and C18:2.

The high concentrations of acid C18:1 trans 11 and CLA C18:2 trans-10 cis-12 observed in the cows subjected to the CS diet may be a result of the longer time of exposure to the supplement, coupled to the lower DMI. The reduction in DMI might have modified the ruminal passage rates, thereby changing the rumen metabolism of the fatty acids from the diet, which probably provided greater biohydrogenation of unsaturated fatty acids. This justification can be proven by the higher concentrations of stearic acid C18:0, end product of the biohydrogenation process, and higher concentrations of acid C18:1 trans-11, for the $\mathrm{CS}$ and $\mathrm{SO}$ diets in relation to diet $\mathrm{C}$, respectively (10.93 and 10.18 vs. 9.13) $(\mathrm{P}<0.05$; Table 4). Another result shows that increasing concentrations of CLA trans-10, cis-12 reduced the fat content of milk for the animals supplemented with diet CS.

According to Kim et al. (2002), diets with a high quantity of concentrate cause deviation in the sequence of biohydrogenation, favoring bacteria like Megasphaera elsdenii. These bacteria utilize lactate as substrate and, as they have the enzyme trans-10 isomerase, they produce the FA CLA trans-10, cis-12 as the first product of biohydrogenation.

Furthermore, the reduction in DMI observed for the animals fed the CS diet in relation to the SO diet (Table 4) may be attributed to the longer exposure time of fatty acids present in supplement for the activity of the rumen bacteria.

Physiologically, according to Piperova et al. (2000), the FA CLA C18:2 trans-10, cis-12 causes changes that can be attributed mainly to the reduction of fatty acids produced by the de novo synthesis in the mammary gland. Although this theory was already accepted by the scientific community, data of recent studies have shown that this process involves several factors. According to Peterson et al. (2003), the reduction of milk fat can be attributed to a series of physiological actions: coordinated decrease in the abundance of mRNA of several genes of enzymes linked to the de novo synthesis in the mammary gland of fatty acids (acetyl CoA carboxylase, fatty acid synthase); consumption and transport of circulating AFA(lipoprotein lipase, FA-binding protein); desaturation of fatty acids ( $\Delta 9$ - desaturase); and the synthesis of triglycerides (fatty acyl CoA ligase, glycerol phosphate acyl trasferase and acyl glycerol phosphate acyl transferase).

This physiological process indicates that all diets containing additional fatty acid sources in this study were at some incomplete rumen biohydrogenation, which could have caused reduction of the $\Delta^{9}$ desaturase enzyme activity, modifying the fat concentrations in milk from cows fed the CS diet (Table 4). Thus, the concentrations of CLA C18:2 cis-9, trans-11 in milk from cows fed calcium salts originate from two sources: ruminal biohydrogenation of polyunsaturated fatty acids in the rumen and endogenous synthesis via $\Delta 9$ desaturase enzyme from the FA trans-11-18:1. (Corl et al., 2001; Piperova et al., 2002).

According to Bauman \& Lock (2006), the biochemical response described above supports the hypothesis that the reduction in fat production involves coordinated regulation of lipogenic enzymes in the mammary gland through the central control of lipid metabolism developed by proteins called SREBP (sterol response element-binding protein).

In this study, the animals fed diets containing fat sources presented lower contents of milk fat, (3.36, 3.11 and 2.81\%) in relation to the animals that received the $\mathrm{C}, \mathrm{SO}$ and $\mathrm{CS}$ diets, respectively (Table 4). Despite the reduction in milk fat content with the triggering of these physiological processes at the expense of higher concentrations of CLA trans-10, cis-12, some studies (Bernal-Santos et al., 2003; Selberg et al., 2004; Medeiros et al., 2010) have shown that this reduction has benefits on the negative energy balance (NEB) by decreasing the energy content excreted in milk, and this favors the increase in the amount of energy retained in the animal body, which in turn reduces the mobilization of body reserves. This is consistent with the data obtained in this study, because the group of cows on the CS diet presented less intense NEB in the transition period (40.32\%) in relation to the SO diet, and about $20.0 \%$ lower in relation to the animals subjected to $\operatorname{diet} \mathrm{C}$, demonstrating the beneficial effect on energy partition (Table 4).

Although there was no difference between CS and SO diets for the concentration of the fatty acid C18:0, the sequence of results indicates that the process of biohydrogenation occurred completely for the animals that received SO diets, while it was incomplete for cows that received the CS diet according to the theory proposed by Bauman \& Griinari (2001) and with the observed concentrations of CLA C18: 2 trans-10 cis-12 throughout the lactation (Cortês et al., 2010).

However, analyzing the concentrations of vaccenic acid, it is necessary to consider, according to Bauman et al. (2000), that the hydrogenation of this fatty acid appears to be a limiting step in the sequence of biohydrogenation because vaccenic acid can be accumulated in the rumen, becoming more available for absorption.

After the absorption, the vaccenic acid is used as substrate for endogenous synthesis of CLA C18: 2 cis-9, trans-11, which involves the enzyme $\Delta 9$ desaturase. 
According to Bauman \& Griinari et al. (2001) and Mosley et al. (2006), the endogenous synthesis of CLA C18:2 cis-9, trans-11 is more important than the ruminal synthesis, accounting for $80 \%$ of CLA C18:2 cis- 9 , trans- 11 found in the milk from cows.

This theory justifies the higher concentrations of CLA C18:2 cis-9, trans-11 observed in the milk from animals that received the $\mathrm{CS}$ and $\mathrm{SO}$ diets (Table 4; $\mathrm{P}<0.05$ ). The diets with fat sources presented higher concentrations of unsaturated fatty acids and lower concentrations of total saturated fatty acids, resulting in higher unsaturated/ saturated fatty acid ratio when compared with the $\mathrm{C}$ diet $(\mathrm{P}<0.05$; Table 4). Similar behavior was observed for the concentrations of total $\mathrm{C} 18$ present in the milk fat $(\mathrm{P}<0.05$; Table 5). There was quadratic effect on the concentrations of total unsaturated fatty acids, and linear effect on the concentrations of total saturated fatty acids along the twelve weeks of lactation $(\mathrm{P}<0.05$; Table 5$)$.

The effects of the week of lactation on crude protein, non-protein nitrogen, non-casein nitrogen, true protein and casein concentrations in the milk can be attributed to the increased milk production over the weeks of lactation, following the lactation curve. This effect is direcly related to the dilution, by the negative correlation between milk yield and solids concentration. The increases in milk production alter the concentration of solids according to the format of the lactation curve throughout the weeks of lactation.

\section{Conclusions}

The utilization of sources of long-chain fatty acids in the diet of dairy cows increases the biological value of milk in early lactation due to higher concentrations of specific fatty acids such as CLA C18: 2 cis-9, trans-11.

\section{References}

ALLEN, M.S. Effects of diet on short-term regulation of feed intake by lactating dairy cattle. Journal of Dairy Science, v.83, p.1598-1624, 2000.

ALLEN, M.S.; BRADFORD, B.J.; HARVATINE, K.J. The cow as a model to study food intake regulation. Annimal Revew Nutrition, v.25, p.523-547, 2005.

ASSOCIATION OF OFFICIAL ANALYTICAL CHEMISTS AOAC. Official methods of analysis. 14.ed. Washington, D.C., 1990.

ASSOCIATION OF OFFICIAL ANALYTICAL CHEMISTS AOAC. Official methods of analysis. 16.ed. Washington, D.C., 1995.

BARBANO, D.M.; CLARK, J.L. Kjeldahl method for determination of total nitrogen content of milk: collaborative study. Journal AOAC International, v.73, n.6, p.849-859, 1990.

BAUMAN, D.E.; BAUMGARD, L.H.; CORL, B.A. et al. Biosynthesis of conjugated linoleic acid in ruminants. Proceedings American Society Animal Science, v.77, p.1-15, 2000.
BAUMAN, D.E.; GRIINARI, J.M. Regulation and nutritional manipulation of milk fat: low-fat milk syndrome. Livestock Production Science, v.70, p.15-29, 2001.

BAUMAN, D.E.; GRIINARI, J.M. Nutritional regulation of milk fat synthesis. Annual Review of Nutrition, v.23, p.203-227, 2003.

BAUMAN, D.E.; LOCK, A.L. Concepts in lipid digestion and metabolism in dairy cows. In: TRI-STATE DAIRY NUTRITION CONFERENCE, 15., 2006, West Lafayette. Proceedings... West Lafayette: Cornell University, 2006. 14p.

BERNAL-SANTOS, G.L.; PERFIELD II, J.W.; BARBANO, D.M. Production responses of dairy cows to dietary supplementation with conjugated linoleic acid (CLA) during the transition period and early lactation. Journal of Dairy Science, v.86, p.3218-3228, 2003.

BYERS, F.M.; SCHELLING, G.T. Los lipidos en la nutricion de los rumiantes. In: CHURCH, D.C. (Ed.) El ruminante fisiología digestiva y nutrición. Zaragoza: Acribia, 1993. p.339-356.

CHILLIARD, Y.; GLASSER, F.; FERLAY, A. et al. Diet, rumen biohydrogenation and nutritional quality of cow and goat milk fat. European Journal of Lipid Science and Technology, v.109, p.828-855, 2007.

CHILLIARD, Y.; FERLAY, A.; MANSBRIDGE, R.M. Ruminant milk fat plasticity: nutritional control of saturated, polyunsaturated, trans and conjugated fatty acids. Annales de Zootechnie, v.49, p.181-205, 2000 .

CLAPPERTON, J.L.; BANKS, W. Factors affecting the yield of milk and its constituents, particularly fatty acids, when dairy cows consume diets containing added fat. Journal of the Science of Food and Agriculture, v.36, p.1205-1211, 1985.

CORL, B.A.; BAUMGARD, L.H.; DWYER, D.A. The role of 9-desaturase in the production of cis-9, trans-11 CLA. Journal of Nutrition Biochemical, v.12, p.622-630, 2001.

CÔRTES, C.; SILVA-KAZAMA, D.C.; KAZAMA, R. et al. Milk composition, milk fatty acid profile, digestion, and ruminal fermentation in dairy cows fed whole flaxseed and calcium salts of flaxseed oil. Journal of Dairy Science, v.93, p.3146-3157, 2010.

FENG, S.; LOCK, A.L.; GARNSWORTHY, P.C. Technical note: A rapid lipid separation method for determining fatty acid composition of milk. Journal of Dairy Science, v.87, p.3785-3788, 2004.

FOLCH, J.; LEES, M.; SLOANE STANLEY, G.H. A simple method for the isolation and purification of total lipides from animal tissues. Journal Biologic Chemical, v.226, p.497-509, 1957.

GARNSWORTHY, P.C. Fat in dairy cow diets. In: WISEMAN, J.; GARNSWORTHY, P.C. (Eds.) Recent developments in ruminant nutrition 4. Nottingham: University Press, 2002. 600p.

GRUMMER, R.R. Effect of feed on the composition of milk fat. Journal of Dairy Science, v.74, p.3244-3257, 1991.

GRUMMER, R.R. Impact of changes in organic nutrient metabolism on feeding the transition dairy cow. Journal of Animal Science, v.73, n.9, p.2820-2833, 1995.

HALL, M.B. Making nutritional sense of nonstructural carbohydrate. In: ANNUAL FLORIDA RUMINANT NUTRITION SYMPOSIUM, 9., 1998, Gainsville, Florida. Proceedings... Gainsville: Florida University Press, 1998. p.108-121.

HARVATINE, K.J.; ALLEN, M.S. Effects of fatty acid supplements on ruminal and total tract nutrient digestion in lactating dairy cows. Journal of Dairy Science, v.89, p.1092-1103, 2006.

JENKINS, T.C.; WALLACE, R.J. MOATE P.J. et al. BOARDINVITED REVIEW: Recent advances in biohydrogenation of unsaturated fatty acids within the rumen microbial ecosystem. Journal Animal Science, v.86, p.397-412, 2008.

KIM, Y.J.; LIU, R.H.; RYCHLIK, J.L. The enrichment of a ruminal bacterium (Megasphaera elsdenii YJ-4) that produces the trans-10, cis-12 isomer of conjugated linoleic acid. Journal of Applied Microbiology, v.92, p.976-982, 2002.

KRAMER, J.K.G.; FELLNER, V.; DUGAN, M.E.R. et al. Evaluating acid and base catalysts in the methylation of milk and rumen fatty 
acids with special emphasis on conjugated dienes and total trans fatty acids. Lipids, v.32, p.1219-1228, 1997.

LYNCH, J.M.; BARBANO, D.M. Indirect and direct determination of the casein content of milk by kjeldahl nitrogen analysis: collaborative study. Journal AOAC International, v.81, n.4, p.763-774, 1998.

MCCARTHY, S.; SMITH, G.H. Synthesis of milk fat from Dhydroxybutyrate and acetate by minant mammary tissue in vitro. Biochimichal Biophys Acta, v.260, p.185-193, 1972.

MEDEIROS, S.R.; OLIVEIRA, D.E.; AROEIRA, L.J.M. et al. Effects of dietary supplementation of rumen-protected conjugated linoleic acid to grazing cows in early lactation. Journal of Dairy Science, v.93, p.1126-1137, 2010.

MOALLEM, U.; KATZ, M.; ARIELI, A. et al. Effects of peripartum propylene glycol or fats differing in fatty acid profiles on feed intake, production, and plasma metabolites in dairy cows. Journal of Dairy Science, v.90, p.3846-3856, 2007.

MOSLEY, E.E.; SHAFII, B.; MOATE, P.J. et al. Cis- 9, trans-11 conjugated linoleic acid is synthesized directly from vaccenic acid in lactating dairy cattle. Journal of Nutrition, v.136, p.570-575, 2006.

NATIONAL RESEARCH COUNCIL - NRC. Nutrient requirements of dairy cattle. 7.ed. Washington, DC: National Academy Press, 2001. 381p.

ONETTI, S.G.; GRUMMER, R.R. Response of lactating cows to three supplemental fat sources as affected by forage in the diet and stage of lactation: A meta-analysis of literature. Animal Feed Science and Technology, v.115, p.65-82, 2004.

PALMQUIST, D. Biohydrogenation then and now. European Journal of Lipid Science and Technology, v.109, p.737-739, 2007.

PALMQUIST, D.L. Influence of source and amount of dietary fat digestibility in lactating cows. Journal Dairy Science, v.74, p.1354-1360, 1991.

PALMQUIST, D.L.; LOCK, A.L.; SHINGFIELD, K.J. et al. Biosynthesis of conjugated linoleic acid in ruminants and humans. Advances in Food and Nutrition Research, v.50, p.179-217, 2005.

PALMQUIST, D.L.; WEISBJERG, M.R.; HVELPLUND, T. Ruminal, intestinal, and total digestibility of nutrients in cows fed diets high in fat and undegradable protein. Journal of Dairy Science, v.76, p.1353-1364, 1993.

PARIZA, M.W. Perspective on the safety and effectiveness of conjugated linoleic acid. The American Journal of Clinical Nutrition, v.79, p.1132-1136, 2004.

PETERSON, D.G.; ELVINA, A.; BAUMAN, D.E. et al. Dietinduced milk fat depression in dairy cows results in increased trans-10, cis-12 CLA in milk fat and coordinate suppression of mrna abundance for mammary enzymes involved in milk fat synthesis. Journal of Nutrition, v.133, p.3098-3102, 2003.

PIPEROVA, L.S.; SAMPUGNA, J.; TETER, B.B. et al. Duodenal and milk trans octadecenoic acid and conjugated linoleic acid (CLA) isomers indicate that postabsorptive synthesis is the predominant source of cis-9-containing CLA in lactating dairy cows. Journal of Nutrition, v.132, p.1235-1241, 2002.

PIPEROVA, L.S.; TETER, B.B.; BRUCKENTAL, I. Mammary lipogenic enzyme activity, trans fatty acids and conjugated linoleic acids are altered in lactating dairy cows fed a milk fat depressing diet. Journal of Nutrition, v.130, p.2568-2574, 2000.

RABIEE, A.R.; BREINHILD, K.; SCOTT, W. et al. Effect of fat additions to diets of dairy cattle on milk production and components: A meta-analysis and meta-regression. Journal of Dairy Science, v.95, p.3225-3247, 2012.

SELBERG, K.T.; LOWE, A.C.; STAPLES, C.R. et al. Production and metabolic response of periparturient Holstein cows to dietary conjugated linoleic acid and trans-octadecenoic acids. Journal of Dairy Science, v.87, p.158-168, 2004.

SMITH, W.A.; HARRIS, B.; VAN HORN, H.H. Effects of forage type on production of dairy cows supplemented with whole cottonseed, tallow, and yeast. Journal Dairy Science, v.76, p.205-215, 1993.

SNIFFEN, C.J.; O'CONNOR, J.D.; VAN SOEST, P.J. et al. A net carbohydrate and protein system for evaluating cattle diets: II. Carbohydrate and protein availability. Journal Animal Science, v.70, p.3562-3577, 1992.

SUKHIJA, P.S.; PALMQUIST, D. L. Rapid method for determination for total fatty acid contend composition of feedstuffs and feces. Journal Agriculture Food Chemical, v.36, p.1202-1206, 1988.

VAN SOEST, P.J.; MASON, V.C. The influence of Maillard reaction upon the nutritive value of fibrous feeds. Animal Feed Science and Technology, v.32, n.1, p.45-53, 1991

WEISS, W.P.; CONRAD, H.R.; PIERRE, N.R. St. A theoreticallybased model for predicting total digestible nutrient values of forages and concentrates. Animal Feed Science and Technology, v.39, p.95-110, 1992.

WHIGHAM, L.D.; COOK, M.E.; ATKINSON, R.L. Conjugated linoleic acid:implications for human health. Pharmacological Research, v.42, p.503-510, 2000.

WU, J.T.; HUBER, S.C.; CHAN, J.M. et al. Effect of source and amount of supplemental fat on lactation and digestion in cows. Journal of Dairy Science, v.77, n.6, p.1644-1651, 1994.

WU, Z.; OHAJURUKA, O.A.; PALMQUIST, D.L. Ruminal synthesis, biohydrogenation, and digestibility of fatty acids by dairy cows. Journal of Dairy Science, v.74, n.9, p.3025-3034, 1991. 